Review Article

\title{
Environmental Disinfection of a Dental Clinic during the Covid-19 Pandemic: A Narrative Insight
}

\author{
Antonio Scarano $\mathbb{D}^{1},{ }^{1}$ Francesco Inchingolo, ${ }^{2}$ and Felice Lorusso ${ }^{1}$ \\ ${ }^{1}$ Department of Medical, Oral and Biotechnological Sciences, University of Chieti-Pescara, Via dei Vestini 31, 66100 Chieti, Italy \\ ${ }^{2}$ Department of Interdisciplinary Medicine, University of Bari “Aldo Moro", 70121 Bari, Italy \\ Correspondence should be addressed to Antonio Scarano; ascarano@unich.it
}

Received 5 September 2020; Revised 27 September 2020; Accepted 16 October 2020; Published 29 October 2020

Academic Editor: Paolo Pesce

Copyright (c) 2020 Antonio Scarano et al. This is an open access article distributed under the Creative Commons Attribution License, which permits unrestricted use, distribution, and reproduction in any medium, provided the original work is properly cited.

\begin{abstract}
Background. The control of biological hazard risk in health care and dental clinic environments represents a critical point in relation to the Covid-19 infection outbreak and international public health emergency. The purpose of the present review was to evaluate the scientific literature on the no-touch disinfection procedures in dental clinics aiming to limit transmission via airborne particles or fomites using no-touch procedures for environmental decontamination of dental clinics. Methods. An electronic database literature search was performed to retrieve research papers about Covid-19 and no-touch disinfection topics including fulllength articles, editorials, commentaries, and outbreak studies. A total of 86 papers were retrieved by the electronic research. Results. No clinical article about the decontamination of a dental clinic during the Covid-19 pandemic was detected. About the topic of hospital decontamination, we found different no-touch disinfection procedures used in hospital against highly resistant organisms, but no data were found in the search for such procedures with respect to SARS-CoV-2: (1) aerosolized hydrogen peroxide, (2) $\mathrm{H}_{2} \mathrm{O}_{2}$ vapor, (3) ultraviolet $\mathrm{C}$ light, (4) pulsed xenon, and (5) gaseous ozone. One paper was retrieved concerning SARS-CoV-2; 32 documents focused on SARS and MERS. The cleaning and disinfection protocol of health care and dental clinic environment surfaces are essential elements of infection prevention programs, especially during the SARS-CoV-2 pandemic. Conclusion. The decontamination technique that best suits the needs of the dental clinic is peroxide and hypochlorous which can be sprayed via a device at high turbine speed with the ability of producing small aerosol particles, recommendable also for their low cost.
\end{abstract}

\section{Background}

A new coronavirus emerged in the central Chinese city of Wuhan in late 2019 [1] and spread rapidly around the world [2] causing the World Health Organization to declare pandemic infection on 11 March 2020 [2]. It is a coronavirus (SARS-CoV-2) that causes pneumonia, moderate to serious respiratory failure, septic shock, and higher risk of death in patients with other pathologies, especially in older people with underlying medical problems like chronic respiratory diseases, cancer, cardiovascular disease, and diabetes $[1,3]$. The Covid-19 disease presents nonspecific symptoms such as conjunctivitis, diarrhea, vomiting, shortness of breath, sore throat, fatigue, and muscular pain, and then, there are also asymptomatic patients [4].
This coronavirus pneumonia has a high percentage mortality rate due to risk factors and mortality predictors such as age $\geq 65$ years, concomitant cardiovascular pathologies, CD3 $+\mathrm{CD} 8+\mathrm{T}$ cell count $\leq 75$ cell $\cdot \mu \mathrm{L}^{-1}$, and cardiac troponin I $\geq 0.05 \mathrm{ng} \cdot \mathrm{mL}^{-1},[5,6]$. In Italy, the number of confirmed cases was 274.644, including 35.518 deaths as of 4 Sept. 2020 , while the great spread of the number of infected cases has caused a lockdown of dental clinical activity and poses a significant risk to personnel dental health care (DHCP) and dental patients. Transmission of SARS-CoV-2 occurs mostly by respiratory droplets over a close distance. It is an aerosol-transmissible disease which can spread when infected people talk, cough, sneeze, or disperse mouth and nasal fomite secretions into the air. Droplets exhaled during speech, sneezes, coughs, and exhalations emit mucosalivary 
droplets with semiballistic trajectories and a multiphase turbulent gas cloud that entrains ambient air and carries within its clusters of droplets with different droplet sizes. In fact, the exhaled air of infected humans is one of the prime sources of ambient contamination by pathogenic microorganisms. Larger droplets may rapidly settle on the ground or transmit disease to individuals in near proximity, while smaller droplets may remain suspended for a long time and can contribute to disease transmission over great distances [7] and for a long time [8]. Today, there is a worldwide pandemic SARS-CoV-2 agent of serious viral pneumonia in course which is being mitigated by lockdown (quarantine and isolation). The transmission routes of the novel coronavirus include direct transmission (aerosol-transmissible) via droplets that "settle" on another individual, while airborne transmission occurs via small droplets in suspension in the air. In particular, airborne transmission can occur without direct contact and at a long distance via air flows (e.g., if an infected person coughs in a room, leaves, and another person enters) as in the restaurant example presented by Lu et al. [9], while the fomite transmission refers to transmission via droplets (usually larger) that settle on surfaces and are then inoculated by contact of the hands with the contaminated surface which then touch nasal, oral, or eye mucous membranes.

Improving ventilation of health spaces will dilute and clear out potentially infectious aerosols $[10,11]$.

Viruses or bacteria take flight and remain in the air so that other people can breathe the airborne pathogenic organisms, or these can land on other surfaces. The locally humid and hot atmosphere within the turbulent gas cloud allows the contained droplets to elude evaporation for longer than occurs with isolated droplets [8].

So, for this reason, it is important to implement respiratory infection control with a good prevention strategy in dental practices and health care offices.

In fact, humans have a high-frequency face-touching habit with an average of 23 times in 1 hour, and hands are a common vector for the transmission of health careassociated infections [12]. When air containing pathogenic airborne microorganisms is inhaled by a human, it can cause tuberculosis or Legionella [13], mycoplasma, or influenza, which are great problems in dentistry practice [14]. In dental practices, droplets from infected patients can contaminate the equipment and surfaces with the risk of transferring microorganisms from contaminated surfaces to other patients through hand contact [14-16]. The high-touch equipment surfaces surrounding the patient increase the risk of contamination of these surfaces.

Furthermore, aerosolized virus, fungi, or bacteria in health care facilities can cause infection in the dentistry equipe and all health care workers [17].

So, it is very important that we adopt a proactive infection control approach to sanitation in the dental clinic between one patient and another to minimize the risk of transmission. We can use the disinfection agents through contact, but this procedure is too long and ineffective, because it is impossible to reach all hidden surfaces. The aims of this article are to discuss and suggest some of the novel notouch disinfection methods in SARS-CoV-2 infection control and prevention of viral transmission in the dental clinic setting, where droplets can be spread by dental tools that aerosolize particles from the mouth, and where surface disinfection is a priority.

In the present review, the scientific literature on the notouch disinfection procedures in dental clinics aiming to limit transmission via airborne particles or fomites or using no-touch procedures for environmental decontamination of dental clinics was evaluated.

\section{Methods}

A 2-stage procedure was followed. The manuscript included for the evaluation was retrieved from PubMed and MEDLINE, and the data were collected on a specially designed Excel database (Microsoft, Redmond, WA, USA). The database search was performed by two expert reviewers (L.F. and A.S.). Moreover, a second step of the manual search was provided to identify manuscripts eligible for descriptive evaluation. The full text and abstract of the papers included were collected and analyzed. Information available from the literature on the no-touch disinfection of dental clinics in the SARS-CoV-2 pandemic era was acquired. A literature search was also performed to retrieve study articles regarding Covid-19 (SARS-CoV-2) and no-touch disinfection in dental clinics. In the present investigation clinical studies, retrospective and prospective trials and reviews in English full-length articles were included. The exclusion criteria were proceedings, short communications, and letters to the editors.

Data was then selected by focusing on the documentation of the measures of no-touch disinfection, and the actual situation of managing SARS-CoV-2 diffusion in the dental clinic. Also taken into consideration were the articles on the measures implemented in hospitals. The literature search was from database inception up to April 30, 2020. Editorials, commentaries, and outbreak studies were included. Studies in which no-touch disinfection methods were used to evaluate the efficacy of reducing contamination of surfaces were also included.

The Boolean search was performed according to the key words used: "disinfectants AND (Covid-19 OR SARS-CoV2 infection)", "no-touch disinfection", "non-manual disinfection techniques", "dentistry equipment surface", "no-touch disinfection AND Covid-19", "dentistry equipment surface contamination", "vapor disinfectant AND dental clinic", and "hospital surfaces contamination and dental clinic contamination".

\section{Results}

A total of 86 papers were retrieved by the electronic research. No data on the clinical experience in the decontamination of dental clinics during the pandemic of Covid-19 were detected.

We found in literature different no-touch disinfection procedures used in hospitals against highly resistant organisms, but no data was found in the search for such procedures with respect to SARS-CoV-2 (Tables 1-9). Different no-touching disinfection systems have been 
TABLE 1: Aerosolized hydrogen peroxide system (aHP) literature.

\begin{tabular}{|c|c|c|c|}
\hline \multicolumn{4}{|c|}{ Aerosolized hydrogen peroxide systems (aHP) } \\
\hline Author & Year & Design & Results \\
\hline Chan et al. [24] & 2011 & $\begin{array}{c}\text { Efficacy of hydrogen peroxide vapor decontamination } \\
\text { on different surfaces of an Australian hospital, seeded } \\
\text { with vancomycin-resistant Enterococci (VRE) }\end{array}$ & $\begin{array}{l}\text { The } 33.3 \% \text { of the high-touch areas assessed } \\
\text { had aerobic bacterial count below the detection } \\
\text { limit post } \mathrm{H}_{2} \mathrm{O}_{2} \text { decontamination, with the } \\
\text { highest microbial density of } \leq 3 \text { c.f.u./cm }\end{array}$ \\
\hline Fu et al. [26] & 2012 & $\begin{array}{l}\text { Efficacy and safety of hydrogen peroxide vapor (HPV) } \\
\text { and aerosolized hydrogen peroxide against } 10(6) \\
\text { methicillin-resistant Staphylococcus aureus (MRSA), } \\
\text { Clostridium difficile, and Acinetobacter baumannii }\end{array}$ & $\begin{array}{l}\text { The HPV system was safer, faster, and more } \\
\text { effective for biological inactivation }\end{array}$ \\
\hline Orlando et al. [27] & 2008 & $\begin{array}{l}\text { Different concentrations }\left(1,2 \text {, and } 4 \mathrm{~mL} / \mathrm{m}^{3}\right) \text { of } \\
\text { the hydrogen peroxide disinfectant were } \\
\text { nebulized inside a } 50 \mathrm{~m}^{3} \text { experimental environment }\end{array}$ & $\begin{array}{c}\text { The reduction of mean bacterial loading at } \\
\text { concentrations of } 1,2 \text {, and } 4 \mathrm{~mL} / \mathrm{m}^{3} \text { was } 54.9 \% \text {, } \\
70.9 \% \text {, and } 86.9 \%\end{array}$ \\
\hline Holmdahl et al. [28] & 2011 & $\begin{array}{l}\text { In vitro comparison of a hydrogen peroxide vapor } \\
\text { (HPV) and aerosolized hydrogen peroxide (aHP) }\end{array}$ & $\begin{array}{l}\text { 1l BIs were inactivated for the } 3 \mathrm{HPV} \text { tests, } \\
\text { compared with only } 10 \% \text { in the first aHP } \\
\text { test and } 79 \% \text { in the other } 2 \mathrm{aHP} \text { tests }\end{array}$ \\
\hline
\end{tabular}

TABLE 2: $\mathrm{H}_{2} \mathrm{O}_{2}$ vapor heat-generated vapor system (aHP) literature.

\begin{tabular}{|c|c|c|c|}
\hline Author & Year & $\begin{array}{l}\mathrm{H}_{2} \mathrm{O}_{2} \text { vapor heat-generated vapor } \\
\text { Design }\end{array}$ & Results \\
\hline Sk et al. [29] & 2011 & $\begin{array}{l}\text { Effect on high strength AISI } 4340 \text { steel after } \\
\text { exposure to vaporized hydrogen peroxide }\end{array}$ & $\begin{array}{l}\text { No effects were produced for samples exposed } \\
\text { to vapor hydrogen peroxide for concentrations } \\
\text { up to } 1000 \text { ppm } \mathrm{H}_{2} \mathrm{O}_{2} \text { and exposure times of } 4.8 \mathrm{~h}\end{array}$ \\
\hline Hall et al. [30] & 2007 & $\begin{array}{l}\text { Effect of hydrogen peroxide vapor (HPV) disinfection } \\
\text { on } M \text {. tuberculosis and Geobacillus stearothermophilus }\end{array}$ & $\begin{array}{l}\text { Both groups were deactivated in all } 10 \text { locations } \\
\text { following } 90 \mathrm{~min} \text { of HPV exposure }\end{array}$ \\
\hline Otter et al. [31] & 2013 & $\begin{array}{l}\text { No-touch automated room disinfection (NTD) } \\
\text { system evaluation }\end{array}$ & $\begin{array}{l}\text { NTD systems are a useful tool for infection } \\
\text { prevention and control }\end{array}$ \\
\hline Berrie et al. [32] & 2011 & $\begin{array}{c}\text { Dried recombinant adenovirus (Ad5GFP) was tested } \\
\text { before and after HPV exposure to determine the } \\
\text { efficacy of hydrogen peroxide vapor HPV at } \\
\text { inactivating adenovirus }\end{array}$ & $\begin{array}{l}\text { HPV is effective for the inactivation of } \\
\text { recombinant adenovirus and decontamination }\end{array}$ \\
\hline Goyal et al. [33] & 2010 & $\begin{array}{l}\text { Efficacy of hydrogen peroxide vapor (HPV) } \\
\text { for the inactivation of Feline calicivirus (FCV) }\end{array}$ & $\begin{array}{l}\text { The hydrogen peroxide resulted in a }>3 \log 10 \\
\text { reduction in FCV infectivity and all but the } 15 \mathrm{~mL}\end{array}$ \\
\hline Jeanes et al. [34] & 2005 & $\begin{array}{c}\text { Hydrogen peroxide vapor (HPV) decontamination } \\
\text { to eradicate MRSA environmental contamination } \\
\text { in a surgical ward }\end{array}$ & $\begin{array}{l}\text { Decontamination using HPV provides a rapid } \\
\text { and cost-effective method for the eradication } \\
\text { of environmental MRSA }\end{array}$ \\
\hline Gopinath et al. [35] & 2013 & $\begin{array}{l}\text { NDM-1 Salmonella Senftenberg (NDM-SS) drug } \\
\text { resistance isolated in a patient. The environment } \\
\text { was disinfected by hydrogen peroxide technology }\end{array}$ & $\begin{array}{l}\text { Decontamination using hydrogen peroxide } \\
\text { technology provides an effective method for } \\
\text { NDM-1 Salmonella Senftenberg (NDM-SS) }\end{array}$ \\
\hline
\end{tabular}

TABLE 3: Dilute hydrogen peroxide (DHP) literature.

\begin{tabular}{|c|c|c|c|}
\hline \multicolumn{4}{|c|}{ Dilute hydrogen peroxide (DHP) } \\
\hline Author & Year & Design & Results \\
\hline Oon et al. [36] & 2011 & $\begin{array}{l}\text { Dilute hydrogen peroxide (DHP) in a critical } \\
\text { care unit and measure the microbiological } \\
\text { impact on surface contamination }\end{array}$ & $\begin{array}{l}\text { Significant reduction in aerobic colony counts } \\
\text { did not occur when the DHP was operating } \\
\text { compared with baseline and control phases }\end{array}$ \\
\hline OSHA guidelines [37] & 2017 & $\begin{array}{c}\text { Samples are collected by drawing workplace air } \\
\text { through two } 25 \mathrm{~mm} \text { quartz filters, coated with } \\
\text { titanium oxysulfate, using personal } \\
\text { sampling pumps }\end{array}$ & $\begin{array}{l}\mathrm{H}_{2} \mathrm{O}_{2} \text { evaporated off the cassette wall and reacted } \\
\text { with the titanium oxysulfate-coated quartz filter }\end{array}$ \\
\hline ILO guidelines [38] & 2017 & $\begin{array}{l}\text { Harmful contamination of the air can } \\
\text { be reached rather quickly on evaporation } \\
\text { of this substance at } 20^{\circ} \mathrm{C}\end{array}$ & $\begin{array}{c}\text { Decomposes under the influence of light on warming } \\
\text { producing oxygen. Increase of fire hazard and is a } \\
\text { strong oxidant. Attacks many organic substances } \\
\text { such as textiles and paper }\end{array}$ \\
\hline
\end{tabular}


TABLE 4: Surface disinfection via aerosol (SDVA) literature.

\begin{tabular}{|c|c|c|c|}
\hline \multicolumn{4}{|c|}{ Surface disinfection via aerosol (SDVA) } \\
\hline Author & Year & Design & Results \\
\hline Boyce et al. [92] & 2016 & $\begin{array}{l}\text { No-touch technologies include aerosol and } \\
\text { vaporized hydrogen peroxide, mobile devices } \\
\text { that emit continuous ultraviolet (UV-C) light, a } \\
\text { pulsed-xenon UV light system, and use of } \\
\text { high-intensity narrow-spectrum }(405 \mathrm{~nm}) \text { light }\end{array}$ & $\begin{array}{l}\text { Environmental departments should consider the } \\
\text { use of newer disinfectants and no-touch } \\
\text { decontamination technologies to improve } \\
\text { disinfection of surfaces in health care }\end{array}$ \\
\hline
\end{tabular}

TABle 5: HOCI generated fog (VHOCI) literature.

\begin{tabular}{|c|c|c|c|}
\hline \multicolumn{4}{|c|}{ HOCI generated fog (VHOCI) } \\
\hline Author & Year & Design & Results \\
\hline Kim et al. [39] & 2008 & $\begin{array}{c}\text { Human primary nasal epithelial cells treated } \\
\text { with } 3.5 \mathrm{ppm} \text { of hypochlorous acid } \\
\text { for cell cytotoxicity }\end{array}$ & $\begin{array}{l}\text { No cytotoxicity at } 30 \text { minutes or } 2 \text { hours } \\
\text { after treatment with } \mathrm{HOCl} \text { was recorded. } \\
\text { More than } 99 \% \text { of bactericidal or fungicidal } \\
\text { activity was noted for all species, except } \\
\text { for Candida albicans }\end{array}$ \\
\hline Park et al. [40] & 2007 & $\begin{array}{c}\text { Efficacy of hypochlorous acid (HOCl) solution } \\
\text { (HAS) to reduce NV in aqueous suspensions } \\
\text { and inanimate carrier }\end{array}$ & $\begin{array}{c}\text { Exposing virus-contaminated carriers of } \\
\text { ceramic tile (porous) and stainless steel (nonporous) } \\
\text { to } 20 \text { to } 200 \mathrm{ppm} \text { of } \mathrm{HOCl} \text { solution resulted } \\
\text { in }>\text { or }=99.9 \% \text { ( }>\text { or }=3 \log 10 \text { ) reductions of } \\
\text { both infectivity and RNA titers of tested viruses } \\
\text { within } 10 \text { min of exposure time }\end{array}$ \\
\hline Russel et al. [41] & 1999 & $\begin{array}{l}\text { Systematic review of sterilization methods, with } \\
\text { uses and advantages outlined for each and valuation } \\
\text { of disinfectants and their mechanisms of action } \\
\text { with respect to current regulations }\end{array}$ & $\begin{array}{l}\text { HOCI generated fog methods effective for the } \\
\text { elimination or prevention/control of } \\
\text { microbial growth }\end{array}$ \\
\hline Yu et al. [42] & 2011 & $\begin{array}{l}\text { Cells were infected with human rhinovirus for } \\
24 \text { hours and treated with HOCl three times, } \\
\text { for } 5 \text { minutes each time, at 12-hour intervals }\end{array}$ & $\begin{array}{l}\text { HOCl treatment significantly inhibited } \\
\text { HRV-induced secretion of IL-6 and IL-8 } \\
\text { and significantly reduced viral titer }\end{array}$ \\
\hline Lister [43] & 1952 & $\begin{array}{l}\text { The rate of decomposition of hypochlorous acid } \\
\text { has been measured in an aqueous solution in the } \\
\text { presence of much sodium hypochlorite }\end{array}$ & $\begin{array}{l}\text { Values for the rate constants at different } \\
\text { temperatures of all these reactions are given. } \\
\text { Measurements are also reported on certain } \\
\text { equilibria present in these solutions: the } \\
\text { ionization of hypochlorous and chlorous } \\
\text { acids, and the reaction }\end{array}$ \\
\hline Hakim et al. [44] & 2014 & $\begin{array}{l}\text { HOCl solutions containing } 50,100 \text {, and } 200 \mathrm{ppm} \\
\text { chlorine or their sprayed solutions were mixed with } \\
\text { the virus with or without organic materials against } \\
\text { a low pathogenic avian influenza virus (AIV), H7N1 }\end{array}$ & $\begin{array}{l}\text { In the indirect spray form, after } 10 \mathrm{sec} \text { of spraying, } \\
\text { the lids of the dishes were opened to expose } \\
\text { the virus on rayon sheets to HOCl. In this form, } \\
\text { the } 200 \text { ppm solution inactivated AIV within } \\
10 \text { min of contact, while } 50 \text { and } 100 \text { ppm could } \\
\text { not inactivate the virus }\end{array}$ \\
\hline
\end{tabular}

proposed such as aerosolized hydrogen peroxide [18], hydrogen peroxide-producing systems [19], $\mathrm{H}_{2} \mathrm{O}_{2}$ vapor [20], hydrogen ultraviolet C light [21], pulsed xenon [22], and gaseous ozone [23].

We found more papers on the efficiency of disinfectant agents on other viruses such as severe acute respiratory syndrome (SARS), Middle East Respiratory Syndrome (MERS), mouse hepatitis virus (MHV), canine coronavirus (CCV), and human coronavirus ( $\mathrm{HCoV})$.

Aerosolized hydrogen peroxide systems (aHP) generate a dry-mist hydrogen peroxide aerosol of hydrogen peroxide and use a solution containing $5 \%-7 \%$ hydrogen peroxide with or without $<50 \mathrm{ppm}$ silver (Nocospay) (Figures 1 and 2) $[24,25]$. The generator injects into a room a solution of HP followed by passive aeration and water and is very active against microorganisms.

This device produces a variable particle size of 2$12 \mu \mathrm{m}$ [26] or of $0.5 \mu \mathrm{m}$ [27]. Generally, a dosage of $6 \mathrm{~mL}$ per $\mathrm{m}^{3}$ is recommended which, after erogation, should be left to decompose naturally. This technique uses a low concentration of hydrogen peroxide which, for this reason, metabolically inert spore and catalase-negative bacteria are less susceptible. It is able to reduce contamination of MRSA and C. difficile on work surfaces but has not been shown to eradicate pathogens in clinical practice. It is difficult to achieve the saturation of the environment because aHP is introduced via a unidirectional nozzle by gravity [28]. 
TABLE 6: UVC light (207-222 nm) literature.

\begin{tabular}{|c|c|c|c|}
\hline \multicolumn{4}{|c|}{ UVC light $(207-222 \mathrm{~nm})$} \\
\hline Author & Year & Design & Results \\
\hline Boyce et al. [45] & 2011 & $\begin{array}{l}\text { Clostridium difficile aerobic colony } \\
\text { counts were calculated for each of } 5 \\
\text { standardized high-touch surfaces in the } \\
\text { rooms before and after UV light } \\
\text { decontamination (UVLD) }\end{array}$ & $\begin{array}{l}\text { The mobile UV-C light unit significantly } \\
\text { reduced aerobic colony counts and C. difficile } \\
\text { spores on contaminated surfaces in patient rooms }\end{array}$ \\
\hline Nerandzic et al. [46] & 2010 & $\begin{array}{c}\text { Cultures for C. difficile, methicillin-resistant } \\
\text { Staphylococcus aureus (MRSA), and } \\
\text { vancomycin-resistant Enterococcus (VRE) were } \\
\text { collected from commonly touched surfaces before } \\
\text { and after the use of an automated ultraviolet } \\
\text { radiation device }\end{array}$ & $\begin{array}{l}\text { Efficient environmental disinfection technology } \\
\text { that significantly reduces } C \text {. difficile, VRE, } \\
\text { and MRSA contamination on commonly } \\
\text { touched hospital surfaces }\end{array}$ \\
\hline Conner-Kerr et al. [47] & 1998 & $\begin{array}{l}\text { UV light ( } 254 \mathrm{~nm}, 15.54 \mathrm{~mW} / \mathrm{cm}^{2} \text { output). } \\
\text { Irradiation times were } 0,2,5,8,15,30,45,60 \text {, } \\
\text { 90, or } 120 \text { seconds in killing antibiotic-resistant } \\
\text { strains of Staphylococcus aureus and } \\
\text { Enterococcus faecalis in vitro }\end{array}$ & $\begin{array}{l}\text { Kill rates were } 99.9 \text { percent for the } \\
\text { methicillin-resistant strain of } S \text {. aureus (MRSA) } \\
\text { at } 5,8,15,30,45 \text {, and } 60 \text { seconds and } 100 \\
\text { percent at } 90 \text { and } 120 \text { seconds. Kill rates } \\
\text { were } 99.9 \text { percent at } 5,8,15 \text {, and } 30 \text { seconds } \\
\text { for vancomycin-resistant E. faecalis (VRE) } \\
\text { and } 100 \text { percent at } 45,60,90 \text {, and } 120 \text { seconds }\end{array}$ \\
\hline Setlow et al. [48] & 1993 & $\begin{array}{l}\text { Irradiated groups of five } 6 \text {-day-old fish with } \\
\text { narrow wavelength bands at } 302,313,365,405 \text {, } \\
\text { and } 436 \mathrm{~nm} \text { and scored the irradiated animals } \\
\text { for melanomas } 4 \text { months later }\end{array}$ & $\begin{array}{l}\text { The light energy absorbed in melanin is } \\
\text { effective in inducing melanomas in this animal } \\
\text { model and that, in natural sunlight, } 90-95 \% \text { of } \\
\text { melanoma induction may be attributed to } \\
\text { wavelengths }>320 \mathrm{~nm} \text { - the UV-A2 } \\
\text { and visible spectral regions }\end{array}$ \\
\hline Welch et al. [49] & 2018 & $\begin{array}{c}\text { Far-UVC light }(207-222 \mathrm{~nm}) \text { efficiently } \\
\text { inactivates bacteria without harm to exposed } \\
\text { mammalian skin }\end{array}$ & $\begin{array}{l}\text { Far-UVC efficiently inactivates aerosolized viruses, } \\
\text { with a very low dose of } 2 \mathrm{~mJ} / \mathrm{cm}^{2} \text { of } 222 \mathrm{~nm} \text { light } \\
\text { inactivating }>95 \% \text { of aerosolized H1N1 influenza virus }\end{array}$ \\
\hline
\end{tabular}

$\mathrm{H}_{2} \mathrm{O}_{2}$ vapor heat-generated vapor. There are two types of HPV: condensing HPV technology and noncondensing vaporized hydrogen peroxide (VHP) technology. This technology uses a vaporizer heated to $120^{\circ} \mathrm{C}$ and circulates the HPV through the environmental chamber via a supply and return hose. Condensing systems inject hydrogen peroxide until the air in the room becomes saturated and HP begins to condense on the surfaces. The condensing of HP on surfaces can cause corrosion [29]. The HPV device injects at $2 \mathrm{~mL} / \mathrm{min}$ for 1,2 , or $5 \mathrm{~min}$ followed by $1.5 \mathrm{~mL} / \mathrm{min}$ for $15 \mathrm{~min}$ equating to three different volumes: 25,27 , and $33 \mathrm{~mL}$.

The level of $1 \mathrm{ppm}$ is the max level of exposure according to the Occupational Safety and Health Administration and International Labour Organisation. This procedure requires a first phase injection and second phase aeration for a total time of approximately 2-3h, varying with the amount of hydrogen peroxide being vaporized.

Noncondensing systems produce dry gas by a vaporized hydrogen peroxide system that utilizes erogation of $30 \%-$ $35 \%$ aqueous hydrogen/peroxide (VHP) at high-velocity air. VHP systems have a generator which delivers until the air in the enclosure becomes saturated and hydrogen peroxide begins to condense on surfaces, and it is designed to achieve a humidity level set prior to the start of the cycle [30]. This system is noncondensing VHP because the vapor stream is dried as it is returned to the generator [31]. It is virucidal, bactericidal, sporicidal, and active against myco- bacteria including C. difficile spores, MRSA, and a wide range of nosocomial pathogens $[32,33]$. Its long cycle times have made it difficult to use this system in health care facilities. It is efficient against fungi, viruses, MRSA, VRE, C. difficile, Klebsiella, Serratia, Mycobacterium tuberculosis, and Acinetobacter [34, 35].

Dilute hydrogen peroxide (DHP). This technique uses water vapor and oxygen in the ambient air to continuously produce ozone-free hydrogen peroxide [36]. The environmental hydrogen peroxide produced is $0.02 \mathrm{ppm}$ that is well below human safety thresholds. In fact, a level of $1 \mathrm{ppm}$ is the max safety level of exposure according to the Occupational Safety and Health Administration and International Labour Organisation [37, 38]. DHP is active against a variety of viruses, bacteria, and fungi. It can be used during routine clinical practice in conjunction with established cleaning and decontamination methods. So, there are no restrictions on the use of a room for a period of time in practices.

Surface disinfection via aerosol (SDVA). The device produces dry fog through a turbine at high speed that atomized and sprays disinfectant. Usually, $\mathrm{H}_{2} \mathrm{O}_{2}$ and hypochlorous acid ( $\mathrm{HOCl}$ ) are used as a disinfectant (Figures 1 and 2). The disinfectant is atomized into ultrafine droplets, blown into the air, and, after 10-30 min, settles on all surfaces; these disinfectant droplets quickly begin to take effect. The generator produces on average size $5 \mu$ particles of disinfectant and ensures a slow and completely uniform sedimentation on each square of the treated premises with no humidity. The 
TABLe 7: PX-UV disinfection system literature.

\begin{tabular}{|c|c|c|c|}
\hline \multicolumn{4}{|c|}{ PX-UV systems } \\
\hline Author & Year & Design & Results \\
\hline Stibich et al. [51] & 2011 & $\begin{array}{l}\text { The use of pulsed-xenon ultraviolet (PX-UV) } \\
\text { room disinfection by sampling frequently } \\
\text { touched surfaces in vancomycin-resistant } \\
\text { enterococci (VRE) isolation rooms }\end{array}$ & $\begin{array}{c}\text { The PX-UV system showed a statistically significant } \\
\text { reduction in microbial load and eliminated VRE on } \\
\text { sampled surfaces when using a 12-minute } \\
\text { multiposition treatment cycle }\end{array}$ \\
\hline Jinadatha et al. [52] & 2014 & $\begin{array}{l}\text { Standard manual room cleaning to PPX-UV } \\
\text { disinfection technology for MRSA and } \\
\text { bacterial heterotrophic plate counts (HPC) } \\
\text { on high-touch surfaces in patient rooms }\end{array}$ & $\begin{array}{l}\text { PPX-UV technology appears to be superior to manual } \\
\text { cleaning alone for MRSA and HPC. Incorporating } \\
15 \text { minutes of PPX-UV exposure time to current } \\
\text { hospital room cleaning practice can improve the } \\
\text { overall cleanliness of patient rooms with } \\
\text { respect to selected microorganisms }\end{array}$ \\
\hline Ghantoji et al. [53] & 2015 & $\begin{array}{l}\text { High-touch surfaces in rooms previously } \\
\text { occupied by } C \text {. difficile-infected patients were } \\
\text { sampled after discharge but before and after } \\
\text { cleaning using either bleach or nonbleach cleaning } \\
\text { followed by } 15 \text { min of PX-UV treatment }\end{array}$ & $\begin{array}{l}\text { After disinfection, the mean level of contamination } \\
\text { for bleach was } 0.71 \text { c.f.u. }(P=0.1380) \text {, and } 1.19 \\
\text { c.f.u. }(P=0.0017) \text { for PX-UV disinfected rooms }\end{array}$ \\
\hline de Groot et al. [90] & 2019 & $\begin{array}{l}\text { UV-C exposure times and distance in killing } \\
\text { C. auris, using strains from different countries }\end{array}$ & $\begin{array}{l}\text { A maximal effect of } C \text {. auris killing was found after } \\
30 \text { minutes of UV-C exposure at } 2 \mathrm{~m} \text {. With half the } \\
\text { time or twice the distance, the efficacy strongly } \\
\text { diminished to } \sim 10 \text { and } \sim 50 \text { fold }\end{array}$ \\
\hline Li et al. [91] & 2020 & $\begin{array}{l}\text { Portable pulsed-xenon ultraviolet (PX-UV) } \\
\text { machine on samples was taken from the } \\
\text { surface of research tables }\end{array}$ & $\begin{array}{l}\text { PX-UV disinfection also significantly reduced } \\
\text { residual bacterial counts }\end{array}$ \\
\hline Yousif and Haddad [54] & 2013 & $\begin{array}{l}\text { UV radiation causes photooxidative degradation } \\
\text { which results in breaking of the polymer chains, } \\
\text { produces free radical, and reduces the molecular } \\
\text { weight, causing deterioration of mechanical } \\
\text { properties and leading to useless materials, } \\
\text { after an unpredictable time }\end{array}$ & $\begin{array}{l}\text { Free hydrogen radicals diffuse very easily through } \\
\text { the polymer matrix and combine in pairs or abstract } \\
\text { hydrogen atoms from polymer molecule }\end{array}$ \\
\hline
\end{tabular}

dry fog is displaced at $15 \mathrm{~m}$ thanks to the venturi effect. This nonwetting and noncorrosive fog can be used for all surfaces including electronic ones and is environmentally friendly. There are two stages for completing disinfection, spraying, and contact time. When the disinfection cycles are completed, it is required to open the windows for almost $10 \mathrm{~min}$. So, the total time required for completing the cycle is $10-30 \mathrm{~min}$. The $\mathrm{H}_{2} \mathrm{O}_{2}$ is nontoxic because it degrades in $\mathrm{H}_{2} \mathrm{O}$ and $\mathrm{O}_{2}$. Hypochlorous acid $(\mathrm{HOCl})$ is a weak acid and has a virucidal power 300 times that of chlorine and is widely used for the decontamination of swimming pools. It is safe and used for nasal irrigation in patients affected by chronic sinusitis. A study showed a low $(0.85 \%)$ concentration $\mathrm{HOCl}$ solution can be used as an effective nasal irrigation solution [39]. Hypochlorous acid ( $\mathrm{HOCl})$ has demonstrated broadspectrum antimicrobial activity while being suitable for general use [40]. 20 to $200 \mathrm{ppm}$ of $\mathrm{HOCl}$ solution resulted in $\geq 99.9 \%$ reduction of noravirus contagion on inanimate surfaces and aqueous suspensions [40], with low potential to damage treated surface materials [41]. The generator produces droplets of size ranging between 20 and $50 \mu \mathrm{m}$. The $\mathrm{HOCl}$ fogs to concentrations ranging from 20 to $200 \mathrm{ppm}$ and has virucidal effect against human norovirus [42]. Fogging is a mechanical action that produces small particles that can accelerate the interfacial mass transmission of chlorine gas. Low concentrations of hypochlorous acid $(\mathrm{HOCl})$ have been demonstrated to exhibit both anti-influenza virus and antibacterial activity, but $\mathrm{HOCl}$ is also used to kill human rhinovirus (HRV) [42]. $\mathrm{HOCl}$ is considered by the FDA the agent that has the highest bactericidal activity against a broad range of microorganisms (US FDA, 2015) [43]. Avian influenza (H5N1) virus inactivation through fog applications of $\mathrm{HOCl}$ was achieved in 10 seconds [44]. $\mathrm{HOCl}$ has a temporary and gentle chlorine smell that dissipates rapidly.

UVC light (207-222 nm) is not visible to the human eye. Ultraviolet C radiation (UVC) emits light (207-222 nm) with efficient bacteria inactivating deliver-specific doses at different powers, for vegetative bacteria $12,000 \mu \mathrm{Ws} / \mathrm{cm}^{2}$ and high power at $22,000-36,000 \mu \mathrm{Ws} / \mathrm{cm}^{2}$ for spores $[45,46]$.

The UV light also inactivates drug-sensitive and multidrug-resistant bacteria and viruses [47].

This technology is very limited because conventional UVC light sources are a human safety hazard, with a carcinogenic effect [48]. For this reason, the power of UVC light has been lowered to $2 \mathrm{~mJ} / \mathrm{cm}^{2}$ and a recent study showed an efficiency when the lamps were positioned in public locations, reducing incidences of transmission of tuberculosis and influenza epidemics [49]. They are very efficient for the disinfection of health care environmental surfaces after manual cleaning has been performed. So, UVC irradiation treatments are effective for inactivating SARS-CoV. A continuous $30 \mathrm{~min}$ ultraviolet radiation is required to disinfect target surfaces and air [50]. 
TABLE 8: Gaseous ozone disinfection literature.

\begin{tabular}{|c|c|c|c|}
\hline \multicolumn{4}{|c|}{ Gaseous ozone } \\
\hline Author & Year & Design & Results \\
\hline Moat et al. [102] & 2009 & $\begin{array}{l}\text { The efficacy of the approach using gaseous } \\
\text { ozone for room sanitization was assessed }\end{array}$ & $\begin{array}{l}\text { Application of the process in a } 30 \mathrm{~m}^{3} \text { room showed } \\
\text { similar reductions in viable counts for } \\
\text { Clostridium difficile spores, Escherichia coli, } \\
\text { and methicillin-resistant Staphylococcus aureus }\end{array}$ \\
\hline Hudson et al. [55] & 2009 & $\begin{array}{l}\text { Develop a practical method of utilizing the } \\
\text { known antiviral properties of ozone in a } \\
\text { mobile apparatus that could be used to } \\
\text { decontaminate rooms in health care facilities }\end{array}$ & $\begin{array}{l}\text { All } 12 \text { viruses tested, on different hard and porous } \\
\text { surfaces, and in the presence of biological fluids, } \\
\text { could be inactivated by at least } 3 \log 10 \text {, in the } \\
\text { laboratory and in simulated field trials }\end{array}$ \\
\hline Rowen [56] & 2019 & $\begin{array}{l}\text { Ozone therapy, the most studied and least } \\
\text { expensive to perform, is in itself a germicide, } \\
\text { not an antibiotic, and improves several } \\
\text { physiological parameters essential for } \\
\text { infection defense }\end{array}$ & $\begin{array}{l}\text { Very favorable responses to both bacterial and viral } \\
\text { disease, inclusive of Ebola. Despite the lack of } \\
\text { commercial profitability (not patentable), } \\
\text { medicine would do well to revisit its preantibiotic } \\
\text { era oxidation therapy roots, especially } \\
\text { ozone in the current crisis }\end{array}$ \\
\hline Hudson et al. [57] & 2007 & $\begin{array}{c}\text { Ability of ozone gas to inactivate norovirus } \\
\text { and its animal surrogate Feline calicivirus (FCV) } \\
\text { in dried samples placed at various locations } \\
\text { within a hotel room, a cruise liner cabin, } \\
\text { and an office }\end{array}$ & $\begin{array}{l}\text { QRT-PCR assays indicated similar decreases in } \\
\text { both viral RNAs. Virus-containing samples dried } \\
\text { onto hard surfaces (plastic, steel, and glass) and } \\
\text { soft surfaces such as fabric, cotton, and carpet } \\
\text { were equally vulnerable to the treatment }\end{array}$ \\
\hline Miller et al. [58] & 2018 & $\begin{array}{l}\text { Acute inhalation of ozone induces DNA } \\
\text { methylation of apelin in the lungs and } \\
\text { if a change in expression is related to } \\
\text { altered DNA methylation in the lung }\end{array}$ & $\begin{array}{c}\text { Ozone exposure reduced DNA } \\
\text { cytosine-5-methyltransferase (DNMT) } \\
\text { activity and Dnmt3a/b gene expression. Epigenetic } \\
\text { modifications accompanied ozone-induced reduction } \\
\text { of apelin expression and development of pulmonary edema }\end{array}$ \\
\hline Ding et al. [103] & 2019 & $\begin{array}{l}\text { Ozone disinfection of chlorine-resistant } \\
\text { bacteria in drinking water }\end{array}$ & $\begin{array}{l}\text { The ozone resistance of bacteria Aeromonas jandaei } \\
<\text { Vogesella perlucida }<\text { Pelomonas }<\text { Bacillus cereus } \\
\quad<\text { Aeromonas sobria was lower than that of } \\
\text { spores Bacillus alvei }<\text { Lysinibacillus fusiformis } \\
<\text { Bacillus cereus at an ozone concentration of } 1.5 \mathrm{mg} / \mathrm{L} \text {. } \\
\text { More than } 99.9 \% \text { of Bacillus cereus spores were inactivated } \\
\text { by increasing ozone concentration and treatment duration }\end{array}$ \\
\hline
\end{tabular}

There is a problem that natural and synthetic polymers are attacked by ultraviolet radiation, materials that make up many parts of a dentist chair, and other medical devices that include polypropylene.

Pulsed-xenon (PX-UV) systems emit high-intensity broad-spectrum UV irradiation in the $200-320 \mathrm{~nm}$ range [51] and are a means of quickly producing germicidal UV [51].

Usually, this is a portable device used in empty patient rooms because prolonged exposure to UV-C can cause eye and skin irritation. Fifteen minutes of PPX-UV exposure time can eliminate the pathogenic microorganisms [52] against $45 \mathrm{~min}$ required to clean a room with bleach [53].

Gaseous ozone is used for environmental disinfection [54]. It has antimicrobial and antiviral properties inclusive of Ebola although its mechanisms of action are not well understood $[55,56]$. The device generates ozone and increases the ozone gas peaking at $20-25 \mathrm{ppm}$ and includes ozone's known corrosive properties [20]. This technology is more efficient when there is low relative humidity [23]. It only takes 3-4 ppm to reduce all viruses and bacteria [57], but at $25 \mathrm{ppm}$, it is a disinfectant, while at $50+\mathrm{ppm}$, it sterilizes surfaces. Ozone can damage the lungs when inhaled, a recent study showed in a rat model that increased methylation of the apelin promoter downstream of DNA damages the lungs, causing the development of pulmonary edema [58].

The generators are unable to elevate ozone levels near the required ppm range even in a small or average-sized room $(<1-5 \mathrm{ppm})$. One to two hours of treatment are needed and 10-15 min of reentry after ventilation or open windows.

\section{Discussion}

During dentistry activity and the use of high-speed drills, droplets that are contaminated with the virus [59] can spread as far as two meters on to exposed surfaces [60] with environmental contamination and these remain infectious on workstation surfaces, medical instruments, etc. at room temperature for up to 9 days [61].

In fact, dental instruments such as rotating devices or ultrasonic devices use high-speed gas to drive the turbine to rotate at high speed and work with running water, and some dental procedures can cause coughing and, in any case, the patient breathes. The airborne droplets are of different dimensions and contain virus or bacteria pathogens which may survive on inanimate surfaces up to several months, and they may serve as a reservoir for cross-contamination 
TABLE 9: Summary for each of the decontamination procedures for instance with the columns procedure, supply required, and threat to human health.

\begin{tabular}{|c|c|c|c|c|}
\hline \multicolumn{5}{|c|}{ Decontamination procedure } \\
\hline Procedure & Supply time & $\begin{array}{l}\text { Deposition } \\
\text { time }\end{array}$ & $\begin{array}{c}\text { Room } \\
\text { ventilation }\end{array}$ & Threat to human health \\
\hline Aerosolized hydrogen peroxide & $6 \mathrm{~min} / 100 \mathrm{~m}^{2}$ & $1-2 \mathrm{~h}$ & $15-30 \mathrm{~min}$ & $\begin{array}{l}\text { Inhalation acute toxicity } 1.93 \mathrm{mg} / \mathrm{M}^{3} \\
\text { Inhalation long-term toxicity } 0.21 \mathrm{mg} / \mathrm{M}^{3}\end{array}$ \\
\hline $\begin{array}{l}\mathrm{H}_{2} \mathrm{O}_{2} \text { vapor heat-generated } \\
\text { vapor }\end{array}$ & $15-50$ min cycle & $\sim 130$ min & $15-20 \mathrm{~min}$ & Eye irritation, odor threshold \\
\hline Surface disinfection via aerosol & $\begin{array}{l}15 \text { minutes at } \\
20^{\circ} \mathrm{C}\end{array}$ & $\sim 2 \mathrm{~h}$ & $\sim 10$ min & Eye irritation and mucosal tissue irritation \\
\hline HOCI generated fog & $10 \mathrm{~min}$ & $30 \mathrm{~min}$ to $2 \mathrm{~h}$ & $20-30 \mathrm{~min}$ & $\begin{array}{l}\text { At prolonged exposure mild inflammatory } \\
\text { reactions to mucosal tissues. At free chlorine } \\
\text { low concentration } \\
\text { pH } 7.0 \text { no toxicity }\end{array}$ \\
\hline Dilute hydrogen peroxide & Continuous & $\sim 2 \mathrm{~h}$ & Not required & $\begin{array}{c}>3 \% \text { hydrogen peroxide: mucosal tissue } \\
\text { irritation, } \\
\text { vomiting and diarrhea. Chronic inhalation: } \\
\text { upper respiratory tract inflammation }\end{array}$ \\
\hline UVC light (207-222 nm) & $60-120 \mathrm{sec} / 30 \mathrm{~m}^{2}$ & $\sim$ & Not required & $\begin{array}{l}\text { At direct exposure temporary damage and burns } \\
\text { to the eyes, cornea, and potential carcinogen } \\
\text { to the skin }\end{array}$ \\
\hline PX-UV systems & $12-30 \mathrm{~min} / 30 \mathrm{~m}^{2}$ & $\sim$ & Not required & Skin and mucosal damage at prolonged exposure \\
\hline Gaseous ozone & $10-30 \mathrm{~min} / 30 \mathrm{~m}^{3}$ & $\sim$ & $10 \mathrm{~min}$ & $\begin{array}{l}\text { Lungs damage, chest pain, coughing, shortness } \\
\text { of breath, and throat irritation }\end{array}$ \\
\hline
\end{tabular}

with self-inoculation, as contaminated hands are a route for disseminating respiratory infections $[62,63]$.

In addition to the infected patients, there are the asymptomatic ones who can be negative to current health status investigations and/or the presence of risk factors for Covid$19[64,65]$. For this reason, all patients must be treated during dental procedure as being Covid-19 positive. Hence, this is a timely topic, and dental clinics would be interested in the state of the art with respect to sanitization procedures. Several studies have found that hygiene quality management in the dental office may be problematic and surface microbial contamination has been found $[66,67]$. All environment surfaces can become contaminated with infectious droplets from sprays of oral fluids or from touching them with contaminated fingers. The surfaces most frequently touched are drawer knobs, light handles, unit switches, dental radiograph equipment, reusable containers of dental materials, drawer handles, and dental chairside computers, and when these devices are touched, microbial agents can be transferred to other instruments [15]. General cleaning and disinfection with chemical or physical agents are recommended for device contact surfaces. It is very important to know material compatibility with physical or liquid chemical germicides. When wiping or scrubbing is used to remove microorganisms, any antimicrobial effect provided by the agent is reduced as there can still be a risk of creating another reservoir for microorganisms in the diluted solutions of the disinfectants themselves [68].

Disinfection of instruments and workstation surfaces against microbial contamination and inefficacy of environmental decontamination could be risk factors for crossinfection. Disinfection of surfaces is a method for reducing the risk of contact to viruses and interrupting their spread [69]. In dentistry, conventional manual disinfection of medical device surfaces is used, and this needs a two-stage disinfection procedure which includes surface rehydration followed by disinfection, for effective inactivation of bacteria and viruses on dry surfaces [70]. It is important to improve ventilation of health care spaces to dilute and clear out potentially infectious aerosols $[10,11]$. Ventilation can reduce virus concentration in the air, limiting airborne transmission, but also the settling of viral particles, causing fomite transmission, for example, in influenza viruses [71]. The use of high ventilation rates during and after aerosol-generating procedures, such as high-speed drills, or piezosurgery [72-75] or between two patients has the potential to efficiently reduce circulating concentration of viral particles.

Environmental disinfection of the dental clinic is very important because the coronavirus can persist on inanimate surfaces like metal, glass, or plastic for up to 9 days, but fortunately, it is very sensitive to the action of disinfectants [61]. A recent correspondence in The New England Journal of Medicine showed that the stability of SARS-CoV-2 was like that of SARS-CoV-1 and was more stable on plastic and stainless steel than on copper and cardboard, and viable virus was detected up to 72 hours after application on these surfaces [76]. Different disinfectant agents were used against severe acute respiratory syndrome (SARS), Middle East Respiratory Syndrome (MERS), mouse hepatitis virus (MHV), canine coronavirus (CCV), and human coronavirus (HCoV) such as ethanol [77], 2-propanol [78], benzalkonium chloride [79], dodecyl dimethyl ammonium chloride $[80,81]$, chlorhexidine digluconate [80], sodium hypochlorite [82], hydrogen peroxide [83], formaldehyde [78], 


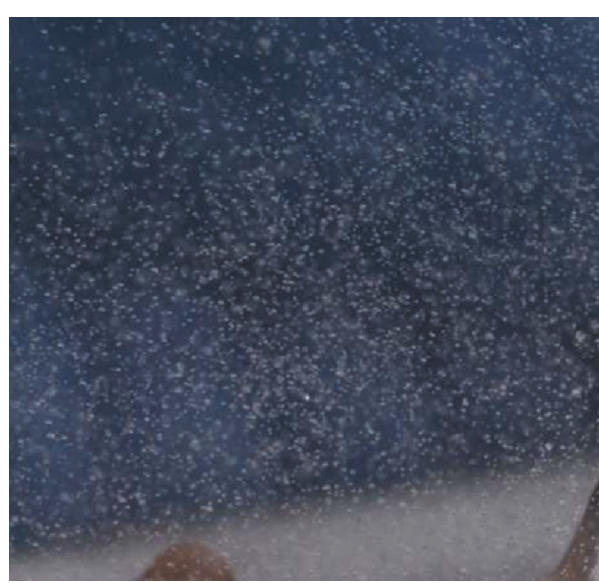

(a)

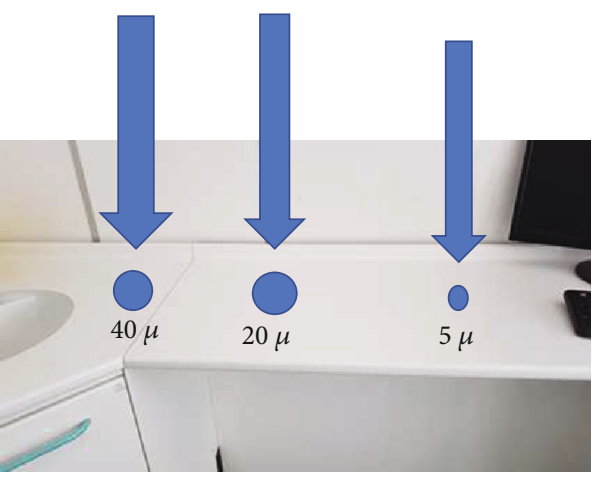

(b)

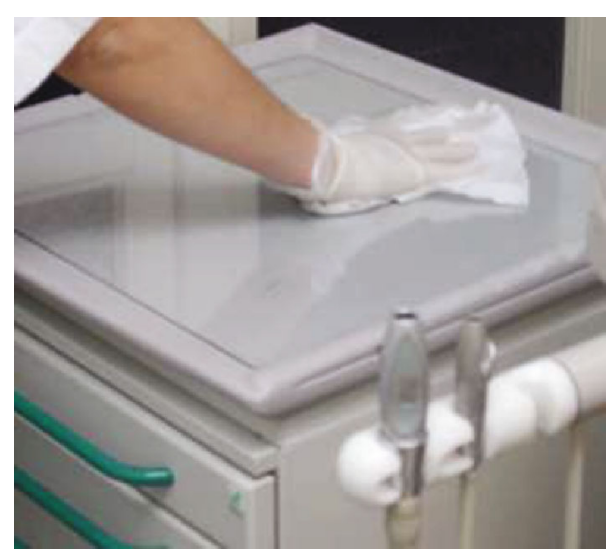

(c)

FIgURE 1: This is a schematic representation as there is no data referenced here in the present paper. (a) Aerosol generating during piezosurgery procedures. (b) Particles of different sizes. Smaller droplets $(5 \mu)$ may remain suspended for a long time and can settle on all environmental surfaces such as drawer knobs, light handles, unit switches, dental radiograph equipment, reusable containers of dental materials, drawer handles, and dental chairside computers and when these devices are touched, microbial agents can be transferred to other instruments. (c) Manual disinfection of medical device surfaces is very difficult.

glutardialdehyde [82], and povidone-iodine [84]. The WHO recommends environmental cleaning and disinfection procedures which must be followed correctly. Benzalkonium chloride and chlorhexidine digluconate are not very effective or basically ineffective.

The most effective disinfectants are ethanol at strong concentration while sodium hypochlorite and hydrogen peroxide require a minimal concentration to be effective with a low impact on human health. Also, ethanol at 62 and $71 \%$ is similarly efficacious against coronavirus but can be used for small surfaces [85]. Ethanol has been widely used for the decontamination of hands based on $80 \%$ ethanol or $75 \%$ 2-propanol, and these are sufficiently efficacious [86].

For cleaning the workstation surfaces, sodium hypochlorite is suitable at a concentration of $0.05 \%$ with efficient and sufficient procedures [85] and when used at a concentration of $0.1 \%$, it is effective in $1 \mathrm{~min}$. Also, hydrogen peroxide is effective with a low concentration of $0.5 \%$ and an action time of $1 \mathrm{~min}$. It is used for cleaning and disinfection implant drills because it preserves the drill structure after 50 cycles of decontamination [87-89].
Thorough decontamination and disinfection of all workstation surfaces in the hospital are very often difficult to achieve on multiple surfaces and complex equipment with wiping or scrubbing and require a lot of time.

For this reason, systems have been proposed, which offer the potential to improve the efficacy and reliability in hospital disinfection of environment and surfaces such as aerosolized hydrogen peroxide [18], hydrogen peroxide-producing systems [19], $\mathrm{H}_{2} \mathrm{O}_{2}$ vapor [20], hydrogen ultraviolet $\mathrm{C}$ light [21], pulsed xenon [22], and gaseous ozone [23].

There are differences between these systems in terms of their effectiveness, technological aspects, and microbiological efficacy. No data were found in the Guidelines for Infection Control in Dental Health-Care Settings 2003 and 2016. UV-C activity against viruses and bacteria is strongly influenced by distance and exposure times and has the most critical parameters; for this reason, a mobile ultraviolet- $\mathrm{C}$ device has been introduced [90]. A recent study showed that $6 \mathrm{~min}$ PX-UV disinfection is required to disinfect target surfaces and air, so it is fast and effective disinfection [91]. PX-UV disinfection is an effective agent for decontaminating the 

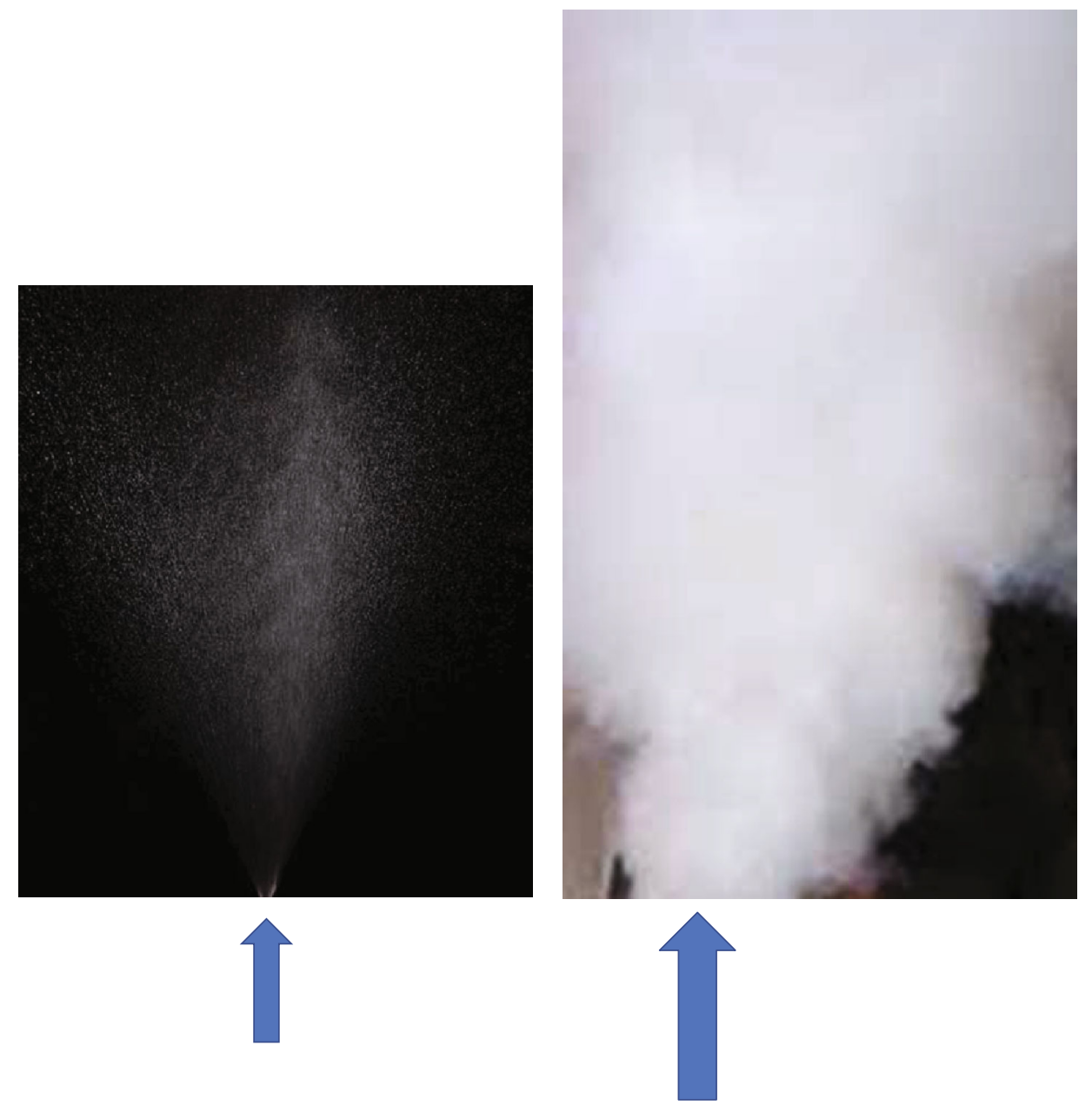

(a)

(b)

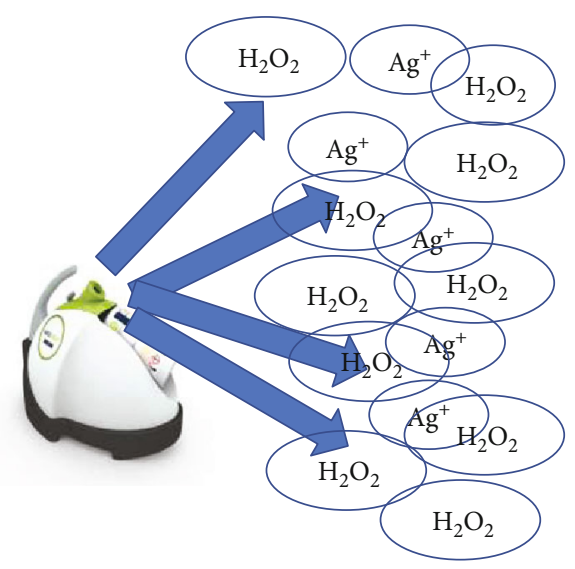

(c)

Figure 2: (a) Difference between nebulization. (b) Generator of dilute hydrogen peroxide. (c) Dry fog generated through a turbine at high speed that atomized and sprays disinfectant (arrows).

workroom. However, UV radiation may cause a significant degradation of synthetic polymers such as polystyrene which results in breaking the polymer chains [54].

The performance of different systems must be evaluated for use in dental practice. The UVC light and PXUV systems are efficacious methods for decontamination of a room, but both systems attack synthetic polymer materials and many parts of dentist chairs and other medical devices can be damaged. The gaseous ozone requires a high concentration and in practice is very difficult to achieve without sealing the doors. So, the most interesting techniques for decontamination in clinical practice are 
VHP and aHP both of which use HP vapor or aerosol and are widely used for environmental decontamination in hospitals [92]. It is desirable that these techniques are also applied to dentistry.

Manual disinfection of work surfaces can result in poor disinfection of work stations with the risk of spreading pathogens from one surface to another [93]. However, there are many variables that influence the efficacy of the manual disinfection process such as distribution and contact time of the agent, which further limit the repeatability and reliance for an operator. For example, quarternary ammonium is an efficacious agent but when used with cotton or wipes containing substantial amounts of cellulose, the antimicrobial efficacy of the disinfectant may be reduced $[94,95]$; therefore, it is recommended to use microfiber [96]. Another error is inappropriate overdilution of disinfectant solutions resulting in inappropriately low concentrations.

Outbreaks and rapid transmission of some viral diseases like rhinovirus, influenza, avian influenza, SARS, and infectious bronchitis, with their elevated morbidity and mortality rates, are generally attributed to infection via aerosol. Droplets produced during the use of high-speed handpieces and air/water syringes with the patient's saliva contaminate the air and floor, all work surface walls, and the objects that are nearby. Then, a no-touch or automatic disinfection approach to disinfection is needed to improve disinfection of surfaces in the dental clinic.

The major problem in clinical practice is that many enteric and respiratory viruses can be shed at great concentrations and contaminate and survive for long periods on environmental and medical device surfaces; this has been shown to play a role in their transmission [97]. HPV is a vapor-phase disinfection method. It is virucidal, including against influenza, and hence can be considered for the environment decontamination and disinfection of viruscontaminated surfaces in the dental clinic.

This technique is also very safe; in fact, it has also been used for the disinfection of N95 respirators with a residual level of $\mathrm{H}_{2} \mathrm{O}_{2}$ on the inner facial filter respirator at a very low level, $0.6 \mathrm{ppm}$ at 2 hours and undetectable at 3 hours when the safety limit is actually lower, being $<1 \mathrm{ppm}$ [98]. Also, HOCI is a fast and simple technique that can be implemented in the dental clinic, since slightly acidic hypochlorous acid water has very fast and strong efficacy against pathogens [99].

Biosecurity programs have a critical role in the control of all infectious diseases. The main way to control and prevent those diseases that are airborne in the hospital or dental clinic is inactivation of infectious agents by spraying disinfectants in the air. HOCI is very popular for its broad and strong disinfection ability, demonstrating a very fast and strong efficacy against avian influenza and many viruses in a short contact time $(5 \mathrm{sec})$, in vitro [44]. It has shown activity also against many bacteria and other microorganisms such as Staphylococcus aureus and Pseudomonas aeruginosa. Application of HOCI in low concentrations 20-200 ppm, by a spraying system with high turbine speed with the ability of producing aerosol particles $(3-10 \mu)$ inside dental clinics, is able to reduce the chances of aerogenic infection causing outbreaks and can limit virus transmission from one site to another. This powerful weapon is 100 percent safe for humans as it occurs naturally in our bodies. Neutrophils are white blood cells that are the first to arrive on site when an invading microorganism is detected. Neutrophils will chase down and engulf the pathogen through phagocytosis. Upon contact, neutrophils release a burst of bactericidal chemicals including its most effective oxidizing agent, $\mathrm{HOCl}$. This inactivates the pathogen by destroying the cell membranes and proteins [100]. All the articles discussed in this review concern the control of infections of very resistant agents (such as norovirus, Ebola, methicillin-resistant Staphylococcus aureus, and C. difficile); for this reason, we can deduce that they are also active against influenza viruses which are much more sensitive to common disinfectants. Very few studies on dental clinics and the identified potential methods to achieve decontamination are detected in literature. So the decontamination technique that best suits the needs of the dental clinic is peroxide and hypochlorous which can be sprayed via a device at high turbine speed with the ability of producing small aerosol particles, recommendable also for their low cost.

These procedures do not replace the correct use of personal protective equipment $[101,102]$. The lower the shed quantity (via the use of masks and safety glasses to limit shedding), the easiest it is to reach noninfectious doses after disinfection, and the lower the exposure dose, the lower the probability to get infected (via the use of masks to limit inoculation) $[103,104]$. Although all dentistry procedures cannot be realized with a mask on the patient, it is important for the dentist to wear correctly one, in addition to colleagues entering the room, and patients in the waiting room for instance. We believe that no-touch methods augment manual cleaning but cannot replace it.

\section{Conclusions}

Dentists should consider the use of these disinfectants and no-touch decontamination technologies to improve disinfection of surfaces in dental clinics. In conclusion, manual cleaning and disinfection of environmental surfaces in health care facilities (daily and at patient discharge) are essential elements of infection prevention programs, especially during the SARS-CoV-2 pandemic.

\section{Abbreviations \\ SARS-CoV-2: Severe acute respiratory syndrome coronavirus \\ Covid-19: $\quad$ Coronavirus 19 \\ UV: Ultraviolet light \\ HAS: Hypochlorous acid solution.}

\section{Conflicts of Interest}

The authors declare that they have no conflicts of interest. 


\section{References}

[1] N. Zhu, D. Zhang, W. Wang et al., "A novel coronavirus from patients with pneumonia in China, 2019," The New England Journal of Medicine, vol. 382, no. 8, pp. 727-733, 2020.

[2] Organization, WH, Coronavirus disease 2019 (COVID-19): situation report, no. 70, 2020.

[3] J. Chen, "Pathogenicity and transmissibility of 2019-nCoV-a quick overview and comparison with other emerging viruses," Microbes and Infection, vol. 22, no. 2, pp. 69-71, 2020.

[4] N. Chen, M. Zhou, X. Dong et al., "Epidemiological and clinical characteristics of 99 cases of 2019 novel coronavirus pneumonia in Wuhan, China: a descriptive study," Lancet, vol. 395, no. 10223, pp. 507-513, 2020.

[5] V. J. Lee, X. Aguilera, D. Heymann et al., "Preparedness for emerging epidemic threats: a lancet infectious diseases commission," The Lancet Infectious Diseases, vol. 20, no. 1, pp. 17-19, 2020.

[6] R.-H. Du, L.-R. Liang, C.-Q. Yang et al., "Predictors of mortality for patients with COVID-19 pneumonia caused by SARS-CoV-2: a prospective cohort study," The European Respiratory Journal, vol. 55, no. 5, p. 2000524, 2020.

[7] X. Xie, Y. Li, H. Sun, and L. Liu, "Exhaled droplets due to talking and coughing," Journal of The Royal Society Interface, vol. 6, Supplement_6, pp. S703-S714, 2009.

[8] L. Bourouiba, "Turbulent gas clouds and respiratory pathogen emissions," JAMA, 2020.

[9] J. Lu, J. Gu, K. Li et al., "COVID-19 outbreak associated with air conditioning in restaurant, Guangzhou, China, 2020," Emerging Infectious Diseases, vol. 26, no. 7, pp. 1628-1631, 2020.

[10] G. A. Somsen, C. van Rijn, S. Kooij, R. A. Bem, and D. Bonn, "Small droplet aerosols in poorly ventilated spaces and SARSCoV-2 transmission," The Lancet Respiratory Medicine, vol. 8, no. 7, pp. 658-659, 2020.

[11] M. Meselson, "Droplets and aerosols in the transmission of SARS-CoV-2," The New England Journal of Medicine, vol. 382, no. 21, p. 2063, 2020.

[12] Y. L. A. Kwok, J. Gralton, and M.-L. McLaws, "Face touching: a frequent habit that has implications for hand hygiene," American Journal of Infection Control, vol. 43, no. 2, pp. 112-114, 2015.

[13] M. T. Montagna, M. L. Cristina, O. D. Giglio et al., "Serological and molecular identification of Legionella spp. isolated from water and surrounding air samples in Italian healthcare facilities," Environmental Research, vol. 146, pp. 47-50, 2016.

[14] X. Peng, X. Xu, Y. Li, L. Cheng, X. Zhou, and B. Ren, “Transmission routes of 2019-nCoV and controls in dental practice," International Journal of Oral Science, vol. 12, no. 1, p. 9, 2020.

[15] D. G. Maki, C. J. Alvarado, C. A. Hassemer, and M. A. Zilz, "Relation of the inanimate hospital environment to endemic nosocomial infection," The New England Journal of Medicine, vol. 307, no. 25, pp. 1562-1566, 1982.

[16] V. Russotto, A. Cortegiani, T. Fasciana et al., "What healthcare workers should know about environmental bacterial contamination in the intensive care unit," BioMed Research International, vol. 2017, Article ID 6905450, 7 pages, 2017.
[17] R. Tellier, Y. Li, B. J. Cowling, and J. W. Tang, "Recognition of aerosol transmission of infectious agents: a commentary," BMC Infectious Diseases, vol. 19, no. 1, p. 101, 2019.

[18] W. A. Rutala and D. J. Weber, "Are room decontamination units needed to prevent transmission of environmental pathogens?," Infection Control \& Hospital Epidemiology, vol. 32, no. 8, pp. 743-747, 2011.

[19] M. E. Falagas, P. C. Thomaidis, I. K. Kotsantis, K. Sgouros, G. Samonis, and D. E. Karageorgopoulos, "Airborne hydrogen peroxide for disinfection of the hospital environment and infection control: a systematic review," The Journal of Hospital Infection, vol. 78, no. 3, pp. 171-177, 2011.

[20] A. Davies, T. Pottage, A. Bennett, and J. Walker, "Gaseous and air decontamination technologies for Clostridium difficile in the healthcare environment," The Journal of Hospital Infection, vol. 77, no. 3, pp. 199-203, 2011.

[21] K. Bedell, A. H. Buchaklian, and S. Perlman, "Efficacy of an automated multiple emitter whole-room ultraviolet- $\mathrm{C}$ disinfection system against coronaviruses MHV and MERSCoV," Infection Control and Hospital Epidemiology, vol. 37, no. 5, pp. 598-599, 2016

[22] P. G. Vianna, C. R. Dale, S. Simmons, M. Stibich, and C. M. Licitra, "Impact of pulsed xenon ultraviolet light on hospital-acquired infection rates in a community hospital," American Journal of Infection Control, vol. 44, no. 3, pp. 299-303, 2016.

[23] D. Zoutman, M. Shannon, and A. Mandel, "Effectiveness of a novel ozone-based system for the rapid high-level disinfection of health care spaces and surfaces," American Journal of Infection Control, vol. 39, no. 10, pp. 873-879, 2011.

[24] H.-T. Chan, P. White, H. Sheorey, J. Cocks, and M.-J. Waters, "Evaluation of the biological efficacy of hydrogen peroxide vapour decontamination in wards of an Australian hospital," The Journal of Hospital Infection, vol. 79, no. 2, pp. 125-128, 2011.

[25] D. Mosci, G. W. Marmo, L. Sciolino et al., "Automatic environmental disinfection with hydrogen peroxide and silver ions versus manual environmental disinfection with sodium hypochlorite: a multicentre randomized before-and-after trial," The Journal of Hospital Infection, vol. 97, no. 2, pp. 175-179, 2017.

[26] T. Y. Fu, P. Gent, and V. Kumar, "Efficacy, efficiency and safety aspects of hydrogen peroxide vapour and aerosolized hydrogen peroxide room disinfection systems," The Journal of Hospital Infection, vol. 80, no. 3, pp. 199-205, 2012.

[27] P. Orlando, M. L. Cristina, M. Dallera, G. Ottria, A. Vitale, and G. Badolati, "Surface disinfection: evaluation of the efficacy of a nebulization system spraying hydrogen peroxide," Journal of Preventive Medicine and Hygiene, vol. 49, no. 3, pp. 116-119, 2008.

[28] T. Holmdahl, P. Lanbeck, M. Wullt, and M. H. Walder, "A head-to-head comparison of hydrogen peroxide vapor and aerosol room decontamination systems," Infection Control and Hospital Epidemiology, vol. 32, no. 9, pp. 831-836, 2011.

[29] M. H. Sk, R. A. Overfelt, R. L. Haney, and J. W. Fergus, "Hydrogen embrittlement of 4340 steel due to condensation during vaporized hydrogen peroxide treatment," Materials Science and Engineering: A, vol. 528, no. 10-11, pp. 36393645, 2011.

[30] L. Hall, J. A. Otter, J. Chewins, and N. L. Wengenack, "Use of hydrogen peroxide vapor for deactivation of Mycobacterium 
tuberculosis in a biological safety cabinet and a room," Journal of Clinical Microbiology, vol. 45, no. 3, pp. 810-815, 2007.

[31] J. A. Otter, S. Yezli, T. M. Perl, F. Barbut, and G. L. French, "The role of "no-touch" automated room disinfection systems in infection prevention and control," The Journal of Hospital Infection, vol. 83, no. 1, pp. 1-13, 2013.

[32] E. Berrie, L. Andrews, S. Yezli, and J. A. Otter, "Hydrogen peroxide vapour (HPV) inactivation of adenovirus," Letters in Applied Microbiology, vol. 52, no. 5, pp. 555-558, 2011.

[33] S. M. Goyal, Y. Chander, S. Yezli, and J. A. Otter, "Hydrogen peroxide vapor (HPV) inactivation of Feline calicivirus, a surrogate for norovirus," in In Proceedings of the Hospital Infection Society (HIS) Conference, 2010.

[34] A. Jeanes, G. Rao, M. Osman, and P. Merrick, "Eradication of persistent environmental MRSA," Journal of Hospital Infection, vol. 61, no. 1, pp. 85-86, 2005.

[35] R. Gopinath, P. Savard, K. C. Carroll, L. E. Wilson, B. M. Landrum, and T. M. Perl, "Infection prevention considerations related to New Delhi metallo- $\beta$-lactamase Enterobacteriaceae: a case report," Infection Control and Hospital Epidemiology, vol. 34, no. 1, pp. 99-100, 2013.

[36] A. Oon, E. Reading, J. K. Ferguson, S. J. Dancer, and B. G. Mitchell, "Measuring environmental contamination in critical care using dilute hydrogen peroxide (DHP) technology: an observational cross-over study," Infection, Disease \& Health, vol. 25, no. 2, pp. 107-112, 2020.

[37] O. Safety and H. Administration, "Occupational safety and health guideline for hydrogen peroxide," Hydrogen Peroxide, 2000, https://www.cdc.gov/niosh/docs/81-123/pdfs/0335 .pdf.

[38] International Labour Organisation, Hydrogen peroxide (>60\% solution in water), 2017.

[39] H. J. Kim, J.-G. Lee, J. W. Kang et al., "Effects of a low concentration hypochlorous acid nasal irrigation solution on bacteria, fungi, and virus," Laryngoscope, vol. 118, no. 10, pp. 1862-1867, 2008.

[40] G. W. Park, D. M. Boston, J. A. Kase, M. N. Sampson, and M. D. Sobsey, "Evaluation of liquid- and fog-based application of Sterilox hypochlorous acid solution for surface inactivation of human norovirus," Applied and Environmental Microbiology, vol. 73, no. 14, pp. 4463-4468, 2007.

[41] A. D. Russel, W. B. Hugo, and J. Ayliffe, Disinfection, Preservation and Sterilization, Blackwell Science, Osney Mead, Oxford, United, 3rd edition edition, 1999.

[42] M. S. Yu, H. W. Park, H. J. Kwon, and Y. J. Jang, "The effect of a low concentration of hypochlorous acid on rhinovirus infection of nasal epithelial cells," American Journal of Rhinology \& Allergy, vol. 25, no. 1, pp. 40-44, 2011.

[43] M. W. Lister, "The decomposition of hypochlorous acid," Canadian Journal of Chemistry, vol. 30, no. 11, pp. 879889, 1952.

[44] H. Hakim, C. Thammakarn, A. Suguro et al., "Evaluation of sprayed hypochlorous acid solutions for their virucidal activity against avian influenza virus through in vitro experiments," Journal of Veterinary Medical Science, vol. 77, no. 2, pp. 211-215, 2015.

[45] J. M. Boyce, N. L. Havill, and B. A. Moore, "Terminal decontamination of patient rooms using an automated mobile UV light unit," Infection Control and Hospital Epidemiology, vol. 32, no. 8, pp. 737-742, 2011.
[46] M. M. Nerandzic, J. L. Cadnum, M. J. Pultz, and C. J. Donskey, "Evaluation of an automated ultraviolet radiation device for decontamination of Clostridium difficile and other healthcare-associated pathogens in hospital rooms," $B M C$ Infectious Diseases, vol. 10, no. 1, p. 197, 2010.

[47] T. A. Conner-Kerr, P. K. Sullivan, J. Gaillard, M. E. Franklin, and R. M. Jones, "The effects of ultraviolet radiation on antibiotic-resistant bacteria in vitro," Ostomy/Wound Management, vol. 44, pp. 50-56, 1998.

[48] R. B. Setlow, E. Grist, K. Thompson, and A. D. Woodhead, "Wavelengths effective in induction of malignant melanoma," Proceedings. National Academy of Sciences. United States of America, vol. 90, no. 14, pp. 6666-6670, 1993.

[49] D. Welch, M. Buonanno, V. Grilj et al., "Far-UVC light: a new tool to control the spread of airborne-mediated microbial diseases," Scientific Reports, vol. 8, no. 1, p. 2752, 2018.

[50] T. Dai, M. S. Vrahas, C. K. Murray, and M. R. Hamblin, "Ultraviolet C irradiation: an alternative antimicrobial approach to localized infections?," Expert Review of AntiInfective Therapy, vol. 10, no. 2, pp. 185-195, 2014.

[51] M. Stibich, J. Stachowiak, B. Tanner et al., "Evaluation of a pulsed-xenon ultraviolet room disinfection device for impact on hospital operations and microbial reduction," Infection Control and Hospital Epidemiology, vol. 32, no. 3, pp. 286288, 2011.

[52] C. Jinadatha, R. Quezada, T. W. Huber, J. B. Williams, J. E. Zeber, and L. A. Copeland, "Evaluation of a pulsed-xenon ultraviolet room disinfection device for impact on contamination levels of methicillin-resistant Staphylococcus aureus," BMC Infectious Diseases, vol. 14, no. 1, p. 187, 2014.

[53] S. S. Ghantoji, M. Stibich, J. Stachowiak et al., "Non-inferiority of pulsed xenon UV light versus bleach for reducing environmental Clostridium difficile contamination on high-touch surfaces in Clostridium difficile infection isolation rooms," Journal of Medical Microbiology, vol. 64, no. 2, pp. 191-194, 2015.

[54] E. Yousif and R. Haddad, "Photodegradation and photostabilization of polymers, especially polystyrene: review," Springerplus, vol. 2, no. 1, p. 398, 2013.

[55] J. B. Hudson, M. Sharma, and S. Vimalanathan, "Development of a practical method for using ozone gas as a virus decontaminating agent," Ozone: Science \& Engineering, vol. 31, no. 3, pp. 216-223, 2009.

[56] R. J. Rowen, "Ozone and oxidation therapies as a solution to the emerging crisis in infectious disease management: a review of current knowledge and experience," Medical Gas Research, vol. 9, no. 4, p. 0, 2019.

[57] J. B. Hudson, M. Sharma, and M. Petric, "Inactivation of norovirus by ozone gas in conditions relevant to healthcare," Journal of Hospital Infection, vol. 66, no. 1, pp. 40-45, 2007.

[58] C. N. Miller, J. A. Dye, M. C. Schladweiler et al., "Acute inhalation of ozone induces DNA methylation of apelin in lungs of Long-Evans rats," Inhalation Toxicology, vol. 30, no. 4-5, pp. 178-186, 2018.

[59] J. Wei and Y. Li, "Airborne spread of infectious agents in the indoor environment," American Journal of Infection Control, vol. 44, no. 9, pp. S102-S108, 2016.

[60] R. Rautemaa, A. Nordberg, K. Wuolijoki-Saaristo, and J. H. Meurman, "Bacterial aerosols in dental practice - a potential hospital infection problem?," The Journal of Hospital Infection, vol. 64, no. 1, pp. 76-81, 2006. 
[61] G. Kampf, D. Todt, S. Pfaender, and E. Steinmann, "Persistence of coronaviruses on inanimate surfaces and their inactivation with biocidal agents," The Journal of Hospital Infection, vol. 104, no. 3, pp. 246-251, 2020.

[62] J. Gu, Y. Zhong, Y. Hao et al., "Preventive behaviors and mental distress in response to H1N1 among university students in Guangzhou, China," Asia Pacific Journal of Public Health, vol. 27, no. 2, pp. NP1867-NP1879, 2015.

[63] H. Nishimura, S. Sakata, and A. Kaga, "A new methodology for studying dynamics of aerosol particles in sneeze and cough using a digital high-vision, high-speed video system and vector analyses," PLoS One, vol. 8, no. 11, article e80244, 2013.

[64] L. Meng, F. Hua, and Z. Bian, "Coronavirus disease 2019 (COVID-19): emerging and future challenges for dental and oral medicine," Journal of Dental Research, vol. 99, no. 5, pp. 481-487, 2020.

[65] Z. Y. Li and L. Y. Meng, "The prevention and control of a new coronavirus infection in department of stomatology," Zhonghua Kou Qiang Yi Xue Za Zhi, vol. 55, article E001, 2020.

[66] A. Smith, S. Creanor, D. Hurrell, J. Bagg, and M. McCowan, "Management of infection control in dental practice," The Journal of Hospital Infection, vol. 71, no. 4, pp. 353-358, 2009.

[67] C. Pasquarella, L. Veronesi, C. Napoli et al., "Microbial environmental contamination in Italian dental clinics: a multicenter study yielding recommendations for standardized sampling methods and threshold values," Science of the total environment, vol. 420, pp. 289-299, 2012.

[68] R. Y. Chinn and L. Sehulster, Guidelines for environmental infection control in health-care facilities; recommendations of CDC and Healthcare Infection Control Practices Advisory Committee (HICPAC), 2003.

[69] M. Dettenkofer and R. C. Spencer, "Importance of environmental decontamination-a critical view," Journal of Hospital Infection, vol. 65, pp. 55-57, 2007.

[70] J. Barker, I. B. Vipond, and S. F. Bloomfield, "Effects of cleaning and disinfection in reducing the spread of norovirus contamination via environmental surfaces," The Journal of Hospital Infection, vol. 58, no. 1, pp. 42-49, 2004.

[71] W. Yang and L. C. Marr, "Dynamics of airborne influenza A viruses indoors and dependence on humidity," PLoS One, vol. 6, no. 6, article e21481, 2011.

[72] A. Scarano, F. Carinci, F. Lorusso et al., "Ultrasonic vs drill implant site preparation: post-operative pain measurement through VAS, swelling and crestal bone remodeling: a randomized clinical study," Materials (Basel), vol. 11, no. 12, p. 2516, 2018.

[73] A. Scarano, A. Piattelli, G. Murmura, G. Iezzi, B. Assenza, and C. Mancino, "Delayed expansion of the atrophic mandible by ultrasonic surgery: a clinical and histologic case series," The International Journal of Oral \& Maxillofacial Implants, vol. 30, no. 1, pp. 144-149, 2015.

[74] A. Scarano, F. Carinci, B. Assenza, M. Piattelli, G. Murmura, and A. Piattelli, "Vertical ridge augmentation of atrophic posterior mandible using an inlay technique with a xenograft without miniscrews and miniplates: case series," Clinical Oral Implants Research, vol. 22, no. 10, pp. 1125-1130, 2011.

[75] A. Scarano, P. Di Domizio, G. Petrone, G. Iezzi, and A. Piattelli, "Implant periapical lesion: a clinical and histologic case report," The Journal of Oral Implantology, vol. 26, no. 2, pp. 109-113, 2000.
[76] N. van Doremalen, T. Bushmaker, D. H. Morris et al., "Aerosol and surface stability of SARS-CoV-2 as compared with SARS-CoV-1," The New England Journal of Medicine, vol. 382, no. 16, pp. 1564-1567, 2020.

[77] H. F. Rabenau, G. Kampf, J. Cinatl, and H. W. Doerr, "Efficacy of various disinfectants against SARS coronavirus," The Journal of Hospital Infection, vol. 61, no. 2, pp. 107111, 2005.

[78] H. F. Rabenau, J. Cinatl, B. Morgenstern, G. Bauer, W. Preiser, and H. W. Doerr, "Stability and inactivation of SARS coronavirus," Medical Microbiology and Immunology, vol. 194, no. 1-2, pp. 1-6, 2005.

[79] A. Wood and D. Payne, "The action of three antiseptics/disinfectants against enveloped and non-enveloped viruses," The Journal of Hospital Infection, vol. 38, no. 4, pp. 283295, 1998.

[80] M. Saknimit, I. Inatsuki, Y. Sugiyama, and K.-I. Yagami, "Virucidal efficacy of physico-chemical treatments against coronaviruses and parvoviruses of laboratory animals," Experimental Animals, vol. 37, no. 3, pp. 341-345, 1988.

[81] A. Pratelli, "Action of disinfectants on canine coronavirus replication in vitro," Zoonoses and Public Health, vol. 54, no. 9-10, pp. 383-386, 2007.

[82] N. Omidbakhsh and S. A. Sattar, "Broad-spectrum microbicidal activity, toxicologic assessment, and materials compatibility of a new generation of accelerated hydrogen peroxidebased environmental surface disinfectant," American Journal of Infection Control, vol. 34, no. 5, pp. 251-257, 2006.

[83] C. Dellanno, Q. Vega, and D. Boesenberg, "The antiviral action of common household disinfectants and antiseptics against murine hepatitis virus, a potential surrogate for SARS coronavirus," American Journal of Infection Control, vol. 37, no. 8, pp. 649-652, 2009.

[84] H. Kariwa, N. Fujii, and I. Takashima, "Inactivation of SARS coronavirus by means of povidone-iodine, physical conditions and chemical reagents," Dermatology, vol. 212, no. 1, Supplement 1, pp. 119-123, 2006.

[85] G. Annex, "Infection Prevention and Control of Epidemicand Pandemic-Prone Acute Respiratory Infections in Health Care," in Use of disinfectants: alcohol and bleach, Geneva, 2014.

[86] A. Siddharta, S. Pfaender, N. J. Vielle et al., "Virucidal activity of World Health Organization-recommended formulations against enveloped viruses, including Zika, Ebola, and emerging coronaviruses," The Journal of Infectious Diseases, vol. 215, no. 6, pp. 902-906, 2017.

[87] A. Scarano, M. Petrini, F. Mastrangelo, S. Noumbissi, and F. Lorusso, "The effects of liquid disinfection and heat sterilization processes on implant drill roughness: energy dispersion X-ray microanalysis and infrared thermography," Journal of Clinical Medicine, vol. 9, no. 4, p. 1019, 2020.

[88] A. Scarano, A. Piattelli, B. Assenza et al., "Infrared thermographic evaluation of temperature modifications induced during implant site preparation with cylindrical versus conical drills," Clinical Implant Dentistry and Related Research, vol. 13, no. 4, pp. 319-323, 2011.

[89] A. Scarano, S. Noumbissi, S. Gupta, F. Inchingolo, P. Stilla, and F. Lorusso, "Scanning electron microscopy analysis and energy dispersion X-ray microanalysis to evaluate the effects of decontamination chemicals and heat sterilization on implant surgical drills: zirconia vs. steel," Applied Sciences, vol. 9, no. 14, p. 2837, 2019. 
[90] T. de Groot, A. Chowdhary, J. F. Meis, and A. Voss, "Killing of Candida auris by UV-C: importance of exposure time and distance," Mycoses, vol. 62, no. 5, pp. 408-412, 2019.

[91] J.-J. Li, S.-N. Wang, J.-J. Qiao et al., "Portable pulsed xenon ultraviolet light disinfection in a teaching hospital animal laboratory in China," Journal of Photochemistry and Photobiology B: Biology, vol. 207, article 111869, 2020.

[92] J. M. Boyce, "Modern technologies for improving cleaning and disinfection of environmental surfaces in hospitals," Antimicrobial Resistance and Infection Control, vol. 5, no. 1, 2016.

[93] J. L. Cadnum, K. N. Hurless, S. Kundrapu, and C. J. Donskey, "Transfer of Clostridium difficile spores by nonsporicidal wipes and improperly used hypochlorite wipes: practice + product = perfection," Infection Control and Hospital Epidemiology, vol. 34, no. 4, pp. 441-442, 2013.

[94] K. Engelbrecht, D. Ambrose, L. Sifuentes, C. Gerba, I. Weart, and D. Koenig, "Decreased activity of commercially available disinfectants containing quaternary ammonium compounds when exposed to cotton towels," American Journal of Infection Control, vol. 41, no. 10, pp. 908-911, 2013.

[95] J. M. Boyce, L. Sullivan, A. Booker, and J. Baker, "Quaternary ammonium disinfectant issues encountered in an environmental services department," Infection Control and Hospital Epidemiology, vol. 37, no. 3, pp. 340-342, 2016.

[96] S. Ali, G. Moore, and A. P. R. Wilson, "Effect of surface coating and finish upon the cleanability of bed rails and the spread of Staphylococcus aureus," The Journal of Hospital Infection, vol. 80, no. 3, pp. 192-198, 2012.

[97] B. Stephens, P. Azimi, M. S. Thoemmes, M. Heidarinejad, J. G. Allen, and J. A. Gilbert, "Microbial exchange via fomites and implications for human health," Current Pollution Reports, vol. 5, no. 4, pp. 198-213, 2019.

[98] V. C. C. Cheng, S.-C. Wong, G. S. W. Kwan, W.-T. Hui, and K.-Y. Yuen, "Disinfection of N95 respirators by ionized hydrogen peroxide during pandemic coronavirus disease 2019 (COVID-19) due to SARS-CoV-2," The Journal of Hospital Infection, vol. 105, no. 2, pp. 358-359, 2020.

[99] D. J. Alexander, "Newcastle disease and other avian paramyxovirus," Revue Scientifique et Technique de l'OIE, vol. 19, no. 2, pp. 443-462, 2000.

[100] A. Degrossoli, A. Müller, K. Xie et al., "Neutrophil-generated $\mathrm{HOCl}$ leads to non-specific thiol oxidation in phagocytized bacteria," eLife, vol. 7, 2018.

[101] A. Scarano, F. Inchingolo, and F. Lorusso, "Facial skin temperature and discomfort when wearing protective face masks: thermal infrared imaging evaluation and hands moving the mask," International Journal of Environmental Research and Public Health, vol. 17, no. 13, p. 4624, 2020.

[102] J. Moat, J. Cargill, J. Shone, and M. Upton, "Application of a novel decontamination process using gaseous ozone," Canadian Journal of Microbiology, vol. 55, no. 8, pp. 928-933, 2009.

[103] W. Ding, W. Jin, S. Cao et al., "Ozone disinfection of chlorine-resistant bacteria in drinking water," Water Research, vol. 160, pp. 339-349, 2019.

[104] F. Lorusso, F. Inchingolo, and A. Scarano, "The impact of the novel Covid-19 on the scientific production spread: a fivemonth bibliometric report of the worldwide research community," Acta Medica Mediterranea, vol. 36, pp. 1-4, 2020. 